\title{
Purification and properties of alkaline phosphatase from boar seminal plasma
}

\author{
S. K. Iyer, H. H. Daron and J. L. Aull* \\ Department of Animal and Dairy Sciences, Alabama Agricultural Experiment Station, and \\ * Department of Chemistry Auburn University, Alabama 36849, U.S.A.
}

\begin{abstract}
Summary. An alkaline phosphatase was purified from boar seminal plasma using adsorption to calcium phosphate gel, gel filtration, and ion-exchange chromatography. The preparation gave a single band on SDS polyacrylamide electrophoresis. The enzyme was a non-specific alkaline phosphatase that hydrolysed pyrophosphate slowly and had no phosphodiesterase activity. The $\mathrm{pH}$ optimum was 10 and the $K_{\mathrm{m}}$ was approximately $0 \cdot 2 \mathrm{~mm}$ with $p$-nitrophenyl phosphate as substrate. The enzyme was a zinc metalloenzyme as indicated by the loss of activity when treated with $o$-phenanthroline and the restoration of activity by zinc and magnesium ions. It also lost activity when treated with thiols. Molecular weight estimates from SDS polyacrylamide gel electrophoresis and gel filtration suggest that the enzyme is a tetramer of identical subunits, each of which has a molecular weight of 68000 .
\end{abstract}

Keywords: alkaline phosphatase; boar semen; purification

\section{Introduction}

Alkaline phosphatase (EC 3.1.3.1) is widely distributed in both the plant and animal kingdoms (McComb et al., 1979). Of vertebrate organs, intestine, placenta, bone, liver and kidney have relatively high concentrations of alkaline phosphatase, and several organ-specific, isoenzymic forms have been partly purified and shown to differ in their catalytic, physical and regulatory properties (Fernley, 1971). Perhaps because of its broad specificity, the precise physiological function of alkaline phosphatase has not been determined, but possible roles in ossification (bone) and nutrient transport (intestine, placenta, liver, kidney and mammary gland) have been suggested (Fernley, 1971).

Alkaline phosphatase is also present in the tissues and secretions of the male genital tract (Bern, 1949). Its concentration in semen varies according to the species, being high in boar and rabbit, intermediate in bull, and low in cock, turkey and human in which much of the total phosphorolytic activity is due to acid phosphatase (Bell \& Lake, 1962). The occurrence of alkaline phosphatase in semen suggests that it plays a role in reproduction, and a correlation between alkaline phosphatase concentration and fertility of bulls has been reported (Stallcup, 1965). So far, no specific reproductive function has been established for seminal alkaline phosphatase, although several possibilities have been suggested (Mann, 1964). Alkaline phosphatase has been purified from the seminal plasma of bull (Strzezek \& Glogowski, 1979), ram (Glogowski \& Strzezek, 1981), and rabbit (Muller, 1983). However, boar seminal plasma would seem to be a preferred source of seminal alkaline phosphatase because it has a higher concentration of enzyme activity than the seminal plasma of any other species reported (Bell \& Lake, 1962) and large volumes of semen can be easily obtained. In this paper we report the purification and partial characterization of the major form of alkaline phosphatase from boar seminal plasma. A preliminary report of this work has been presented (Iyer et al., 1986). 


\section{Materials and Methods}

\section{Materials}

The D- and L-p-bromotetramisole oxalate were obtained from Aldrich Chemical Co., Inc., Milwaukee, WI. $p$ Nitrophenylphosphate, acetylphosphate, bis-( $p$-nitrophenyl)-phosphate, 5-bromo-4-chloro-3-indolyl phosphate, fructose 6-phosphate, fructose 1,6-bisphosphate, glucose 6-phosphate, glycerol 1-phosphate, glycerol 2-phosphate, NADP, D,L-dithiothreitol, glutathione (oxidized), 2-amino-2-methyl-1-propanol (AMP), tris-(hydroxymethyl)aminomethane (Tris), Sephacryl S-300, DEAE-Sephadex (A-50), and CM-Sephadex (C-50) were obtained from Sigma Chemical Co., St Louis, MO. Electrophoretic materials were obtained from Bio-Rad Laboratories, Richmond, CA, and Eastman Kodak Co., Rochester, NY. Molecular weight standards for SDS electrophoresis and gel filtration were obtained from Pharmacia Fine Chemicals, Piscataway, NJ. All other chemicals were reagent grade and were used without further purification.

Calcium phosphate gel was prepared according to Keilin \& Hartree (1938). It was stored in the dark and allowed to age at least 1 month before use.

Seminal plasma was obtained by straining fresh boar semen through cheesecloth and centrifuging at $\sim 10000 \mathrm{~g}$ for $15 \mathrm{~min}$. The seminal plasma was stored at $-70^{\circ} \mathrm{C}$ until used.

\section{Methods}

Enzyme assay. The alkaline phosphatase assay was a modification of the original method of Bessey et al. (1946), which was based on the spectrophotometric measurement of $p$-nitrophenol produced by the enzyme-catalysed hydrolysis of $p$-nitrophenylphosphate. The reaction mixture contained $0.12 \mathrm{M}$-AMP buffer, $\mathrm{pH} 10,2 \mathrm{~mm}-p$ nitrophenylphosphate, and enzyme in a total volume of $0.5 \mathrm{ml}$. The reaction was started by adding substrate to the reaction mixture, which was incubated for $15 \mathrm{~min}$ at $30^{\circ} \mathrm{C}$, and was stopped by adding $3.5 \mathrm{ml} 0.1 \mathrm{~N}-\mathrm{NaOH}$. The absorbance at $405 \mathrm{~nm}$ was measured spectrophotometrically (Model 250: Gilford Instrument Laboratories, Inc., Oberlin, $\mathrm{OH}$ ) and was converted to $\mu$ moles by using a molar absorptivity of $18000 \mathrm{~m}^{-1} \mathrm{~cm}^{-1}$. One unit of enzyme activity is that amount which produces $1 \mu \mathrm{mol} p$-nitrophenol per min under the conditions described. Specific activity is expressed as units of activity per $\mathrm{mg}$ protein.

Protein determination. Protein was determined by the method of Lowry et al. (1951) with bovine serum albumin as the protein standard.

Polyacrylamide gel electrophoresis. Non-denaturing polyacrylamide gel electrophoresis was performed with tube gels by the method of Davis (1964). Sodium dodecylsulphate polyacrylamide gel electrophoresis was performed in a 10-20\% linear gradient of polyacrylamide (O'Farrell, 1975) using a vertical slab gel apparatus (Bio-Rad Laboratories). Samples were denatured by heating at $100^{\circ} \mathrm{C}$ for about $10 \mathrm{~min}$ in Tris $\mathrm{Cl}$ buffer, $\mathrm{pH} 6.8$, containing $2 \%$ SDS and $10 \%$ glycerol. Some samples were reduced by including 5\% 2-mercaptoethanol in the denaturing buffer. Proteins were detected with Coomassie Brilliant Blue R-250, glycoproteins with periodate-Schiff reagent (Arinc, 1974), and alkaline phosphatase activity with the substrate 5-bromo-4-chloro-3-indolyl phosphate (Starkweather \& Searcy, 1975).

Alkaline phosphatase purification. The initial steps through Sephacryl S-300 chromatography were similar to those previously described for the purification of $\beta$-hexosaminidase (Daron \& Aull, 1985). Seminal plasma (140 ml) was diluted with 3 volumes of cold distilled water and centrifuged at $20000 \mathrm{~g}$ for $15 \mathrm{~min}$. The $\mathrm{pH}$ of the supernatant solution was brought to 5.6 by adding $1 \mathrm{~N}$-acetic acid. A one-fifth volume of cold calcium phosphate gel suspension $(\sim 25 \mathrm{mg}$ solids $/ \mathrm{ml})$ was added. The mixture was stirred slowly for $15 \mathrm{~min}$ and centrifuged. The resulting pellet of calcium phosphate gel was suspended in $200 \mathrm{ml} 0.3 \mathrm{M}$-potassium phosphate buffer, $\mathrm{pH} 6.4$, containing $0.5 \mathrm{M}-\mathrm{NaCl}$ to elute adsorbed protein. After $30-60 \mathrm{~min}$, the suspension was centrifuged and the supernatant solution retained. The elution was repeated with $100 \mathrm{ml}$ of the same buffer solution. The combined eluates were concentrated with a Millipore immersible CX-30 ultrafilter, dialysed against $20 \mathrm{~mm}$-potassium phosphate buffer, $\mathrm{pH} 8$, and chromatographed on Sephacryl S-300. Fractions containing alkaline phosphatase activity were combined and applied to a $1.7 \times 30 \mathrm{~cm}$ column containing DEAE-Sephadex, which had been equilibrated with $20 \mathrm{~mm}$-potassium phosphate buffer, $\mathrm{pH}$ 8. After eluting the column with 4 column volumes of equilibration buffer, the remaining proteins were eluted with $200 \mathrm{ml}$ of the same buffer containing a linear gradient of potassium chloride from 0 to $0.5 \mathrm{M}$. The alkaline phosphatase activity that eluted before the start of the salt gradient was pooled, concentrated using a Millipore immersible CX-30 ultrafilter (30000 nominal molecular weight limit), and dialysed overnight against 40 times its volume of $50 \mathrm{~mm}$-phosphate buffer, $\mathrm{pH}$. The preparation from the above step was applied to a $1.7 \times 30 \mathrm{~cm} \mathrm{CM}$ Sephadex column equilibrated with $50 \mathrm{~mm}$-phosphate buffer, $\mathrm{pH} 7$. The column was washed with equilibration buffer to remove unadsorbed protein and then eluted with equilibration buffer containing potassium phosphate in a linear gradient from 0 to $0.5 \mathrm{M}(100 \mathrm{ml}$ in mixing chamber and $100 \mathrm{ml}$ in reservoir). Alkaline phosphatase activity was eluted at about $0.3 \mathrm{M}$-phosphate. The active fractions were combined, concentrated with a Millipore immersible CX-30 ultrafilter, and dialysed overnight against 40 times its volume of $20 \mathrm{~mm}$-potassium phosphate buffer, $\mathrm{pH} \mathrm{8.0.} \mathrm{The}$ resulting solution was labeled CM eluate and was used in all subsequent experiments. 


\section{Results}

Alkaline phosphatase was purified 102-fold from boar seminal plasma. Results of a typical purification are summarized in Table 1 . The specific activity of the CM eluate was $17 \mathrm{units} / \mathrm{mg}$, which is about 5 times greater than that reported for the most active homogeneous enzyme preparation from bull seminal plasma (Strzezek \& Glogowski, 1979) even though the latter was assayed at $37^{\circ} \mathrm{C}$. During DEAE-Sephadex chromatography, approximately $80 \%$ of the recovered activity passed through the column unretarded while the other $20 \%$ was retained and was subsequently eluted with $\mathrm{NaCl}$. Boar seminal plasma may therefore contain 2 forms of alkaline phosphatase and, in that regard, is similar to the seminal plasma of the bull, which contains 2 forms of the enzyme (Strzezek \& Glogowski, 1979), and of the ram, which contains 3 forms (Glogowski \& Strzezek, 1981). The minor fraction contained glycosidases and was not investigated further. The major fraction is designated 'DEAE eluate' in Table 1 and was subsequently chromatographed on CM-Sephadex. The heterogeneity of the final preparation was examined using polyacrylamide disc gel electrophoresis. In the absence of Triton X-100, alkaline phosphatase activity did not enter the gel and remained at the gel surface, but with Triton X-100, a portion of the alkaline phosphatase activity entered the gel as a single band that coincided with the only detectable protein band (Fig. 1). The alkaline phosphatase that remained at the surface was presumably an aggregate similar to that reported from other tissues (Hascall \& Sajdera, 1969; Vittur \& Debernard, 1973). The gel stained with Schiff's reagent after periodate oxidation showed that this alkaline phosphatase is a glycoprotein (Fig. 1). The final preparation also gave a single band on SDS polyacrylamide gel electrophoresis.

Table 1. Purification of alkaline phosphatase from $140 \mathrm{ml}$ of boar seminal plasma

\begin{tabular}{lccccc}
\hline Fraction & $\begin{array}{c}\text { Total } \\
\text { activity } \\
\text { (units) }\end{array}$ & $\begin{array}{c}\text { Protein } \\
\text { conc. } \\
\text { (mg/ml) }\end{array}$ & $\begin{array}{c}\text { Specific } \\
\text { activity } \\
\text { (units/mg) }\end{array}$ & $\begin{array}{c}\text { Yield } \\
(\%)\end{array}$ & Purification \\
\hline Seminal plasma & 702 & $30 \cdot 5$ & $0 \cdot 167$ & 100 & 1 \\
Diluted SP & 685 & $5 \cdot 60$ & $0 \cdot 223$ & $97 \cdot 7$ & $1 \cdot 3$ \\
CP eluate & 660 & $5 \cdot 05$ & 1.04 & $94 \cdot 1$ & $6 \cdot 3$ \\
S300 eluate & 342 & $3 \cdot 10$ & $4 \cdot 01$ & $48 \cdot 7$ & $24 \cdot 0$ \\
DEAE eluate & 70 & $0 \cdot 58$ & $6 \cdot 72$ & $10 \cdot 0$ & $40 \cdot 2$ \\
CM eluate & 34 & $0 \cdot 20$ & $17 \cdot 1$ & $4 \cdot 9$ & 102 \\
\hline
\end{tabular}

The enzyme preparation was active with a variety of phosphate esters but had little or no activity with acid anhydrides (Table 2). L-p-Bromotetramisole oxalate, an inhibitor of non-specific alkaline phosphatase (Van Belle et al., 1977), completely inactivated the enzyme at a concentration of $50 \mathrm{~mm}$, while concentrations up to $200 \mathrm{~mm}$ of the D-isomer had no effect on enzyme activity. The enzyme was not active with bis-( $p$-nitrophenyl) phosphate as substrate, indicating that it had no phosphodiesterase activity. With $p$-nitrophenylphosphate as substrate, the enzyme exhibited Michaelis-Menten kinetics with a $K_{\mathrm{m}}$ of approximately $0.2 \mathrm{~mm}$. The optimum $\mathrm{pH}$ of the enzyme was 10 with carbonate-bicarbonate buffer or AMP buffer (Fig. 2). The activity was greater with AMP buffer because it acts as a phosphoryl acceptor and increases the formation of $p$-nitrophenol.

The enzyme lost $95 \%$ of its activity when incubated with $2.5 \mathrm{~mm}-o$-phenanthroline (Fig. 3 ). About $90 \%$ of the activity was restored by treating the inactivated enzyme with $0.5 \mathrm{~mm}-\mathrm{ZnSO}_{4}$ in the presence of $2.5 \mathrm{~mm}-\mathrm{Mg}^{2+}$. Concentrations of zinc higher than $0.5 \mathrm{~mm}$ inhibited the reactivation process. Neither $\mathrm{Zn}^{2+}$ nor $\mathrm{Mg}^{2+}$ alone restored activity. Inactivation with $o$-phenanthroline and regeneration by added zinc ions suggests that the enzyme is a zinc (II) metalloprotein.

The influence of temperature on the rate of heat inactivation is shown in Fig. 4. The enzyme lost half its activity when heated to $55^{\circ} \mathrm{C}$ for $15 \mathrm{~min}$. The rate of heat inactivation was influenced by the presence of $\mathrm{NaCl}$ or potassium phosphate. Both increased the rate of heat inactivation with the 


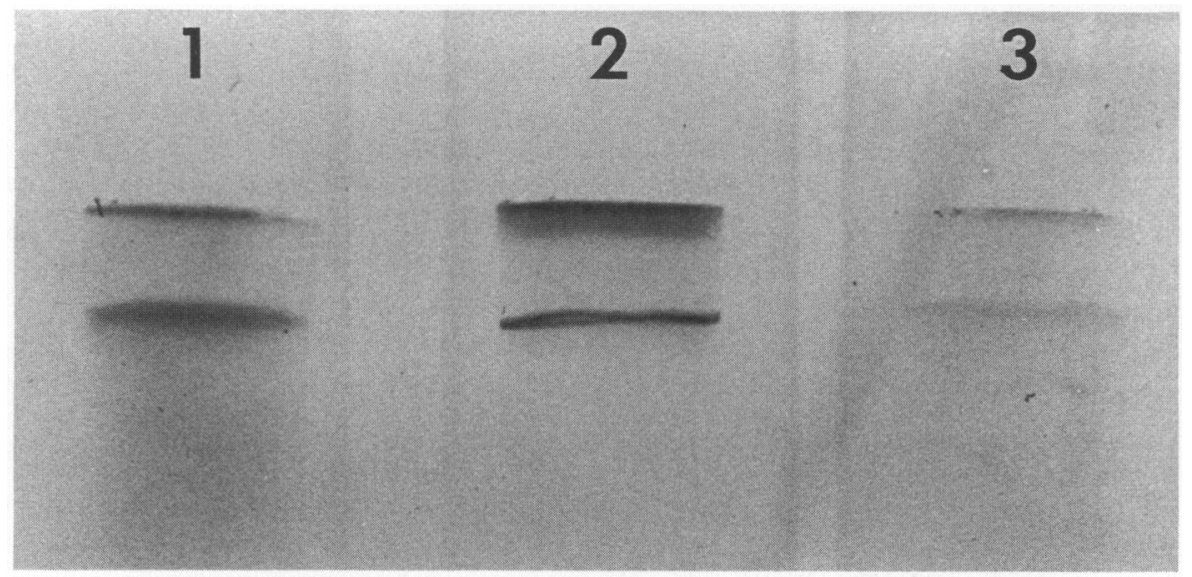

Fig. 1. Polyacrylamide gel electrophoresis. Purified alkaline phosphatase was treated with $0 \cdot 5 \%$ Triton X-100 and electrophoresed on 7.5\% non-denaturing gels containing $0.5 \%$ Triton X-100. The gels were stained for protein (gel 1), enzymic activity (gel 2), and glycoprotein (gel 3).

Table 2. Substrate specificity

\begin{tabular}{lcc}
\hline & \multicolumn{2}{c}{ Activity } \\
\cline { 2 - 3 } Substrate & Units & $\%$ \\
\hline$p$-Nitrophenyl phosphate & $1 \cdot 267$ & 100 \\
NADP & $1 \cdot 21$ & $95 \cdot 5$ \\
Fructose 1,6-bisphosphate & $0 \cdot 867$ & $68 \cdot 4$ \\
Glycerol 2-phosphate & $0 \cdot 787$ & $62 \cdot 1$ \\
Glycerol 1-phosphate & $0 \cdot 540$ & $42 \cdot 6$ \\
Glucose 6-phosphate & $0 \cdot 533$ & $42 \cdot 1$ \\
Fructose 6-phosphate & $0 \cdot 226$ & $17 \cdot 8$ \\
Sodium pyrophosphate & $0 \cdot 093$ & $7 \cdot 3$ \\
Acetyl phosphate & 0 & 0 \\
\hline
\end{tabular}

exception of low concentrations of potassium phosphate, which had a slight stabilizing effect (Fig. 4b).

The enzyme lost all its activity after incubation for $30 \mathrm{~min}$ at $30^{\circ} \mathrm{C}$ with $0.1 \mathrm{~mm}$-dithiothreitol (Fig. 5a). About $30 \%$ of the original enzyme activity was recovered after incubation with $0.5 \mathrm{~mm}$ oxidized glutathione, but activity was not restored by dialysis (Fig. 5b). The enzyme was also inactivated by $100 \mathrm{~mm}-2$-mercaptoethanol and overnight dialysis resulted in regeneration of $90 \%$ of the activity.

SDS polyacrylamide gel electrophoresis showed a single band corresponding to a subunit molecular weight of $\sim 69000$ when the purified enzyme preparation was denatured in the presence or absence of 2-mercaptoethanol (Fig. 6). The molecular weight of the native enzyme was 290000 by size exclusion chromatography on Sephacryl S-300, suggesting that the native enzyme is a tetramer composed of 4 identical subunits. 


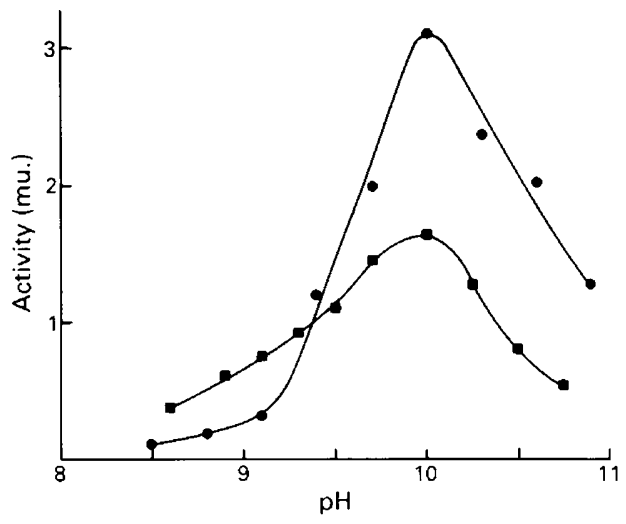

Fig. 2. Effect of $\mathrm{pH}$ on alkaline phosphatase activity. Each reaction mixture contained $0 \cdot 12 \mathrm{M}$ carbonate-bicarbonate buffer $(\boldsymbol{\square})$ or $0.12 \mathrm{M}$-AMP buffer $(\boldsymbol{O})$ at the $\mathrm{pH}$ values shown, $2 \mathrm{~mm}-\mathrm{p}$ nitrophenylphosphate, and enzyme in a total volume of $0.5 \mathrm{ml}$. Reactions were conducted at $30^{\circ} \mathrm{C}$ for $15 \mathrm{~min}$ and stopped by adding $3.5 \mathrm{ml} 0.1 \mathrm{~N}-\mathrm{NaOH}$. The absorbance at $405 \mathrm{~nm}$ was measured. Each point is the average of 3 determinations.

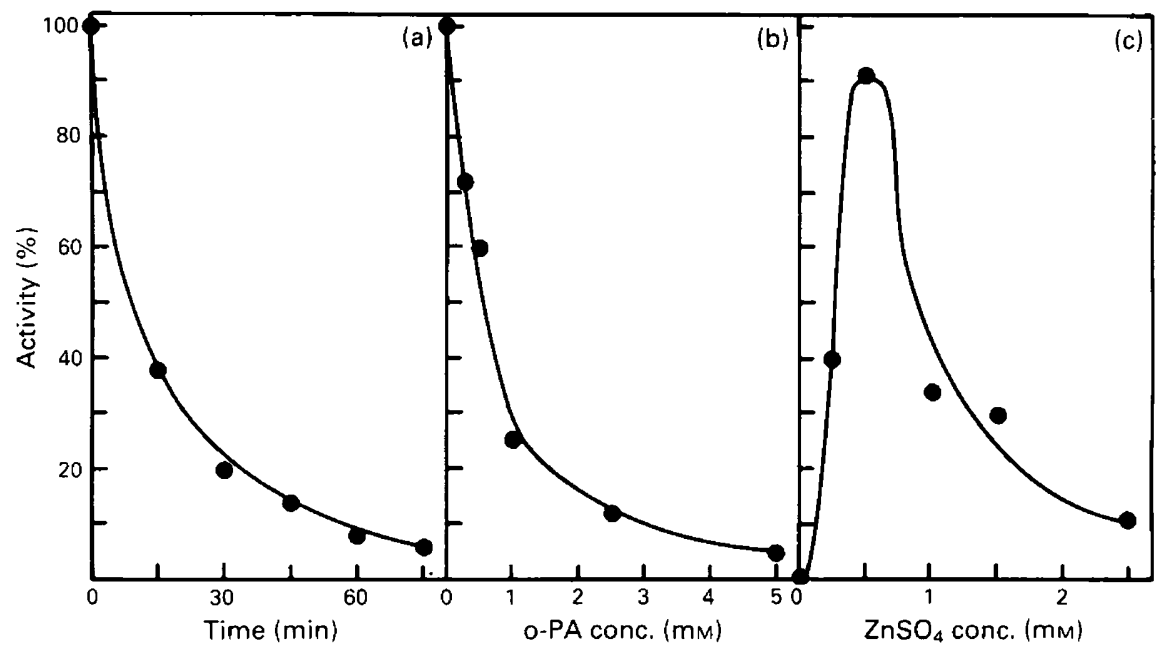

Fig. 3. Effect of $o$-phenanthroline and zinc ions on alkaline phosphatase activity. (a) A solution of 0.17 units of purified alkaline phosphatase $/ \mathrm{ml}$ in $18 \mathrm{~mm}$-potassium phosphate buffer, $\mathrm{pH} 7 \cdot 5$, containing $2.5 \mathrm{~mm}-o$-phenanthroline was incubated at $30^{\circ} \mathrm{C}$. At the times shown, $0.1 \mathrm{ml}$ aliquants were withdrawn and assayed for alkaline phosphatase activity. (b) The reaction mixtures and the procedure were the same as described in Fig. 3(a) except that $o$-phenanthroline concentrations were as shown and the incubation period was $60 \mathrm{~min}$. (c) Aliquants of alkaline phosphatase that had been inactivated by incubation for $1 \mathrm{~h}$ in the presence of $5 \mathrm{~mm}-o$-phenanthroline were added to equal volumes of $\mathrm{ZnSO}_{4}$ to give the final concentrations shown. After incubation for an additional $30 \mathrm{~min}$, aliquants were withdrawn and assayed for alkaline phosphatase activity.

\section{Discussion}

The catalytic properties of alkaline phosphatase from boar seminal plasma were similar to those of other seminal alkaline phosphatases. The value of the Michaelis constant with $p$-nitrophenyl phosphate as substrate $(0.2 \mathrm{~mm})$ was essentially the same as those reported for the two forms from bull 


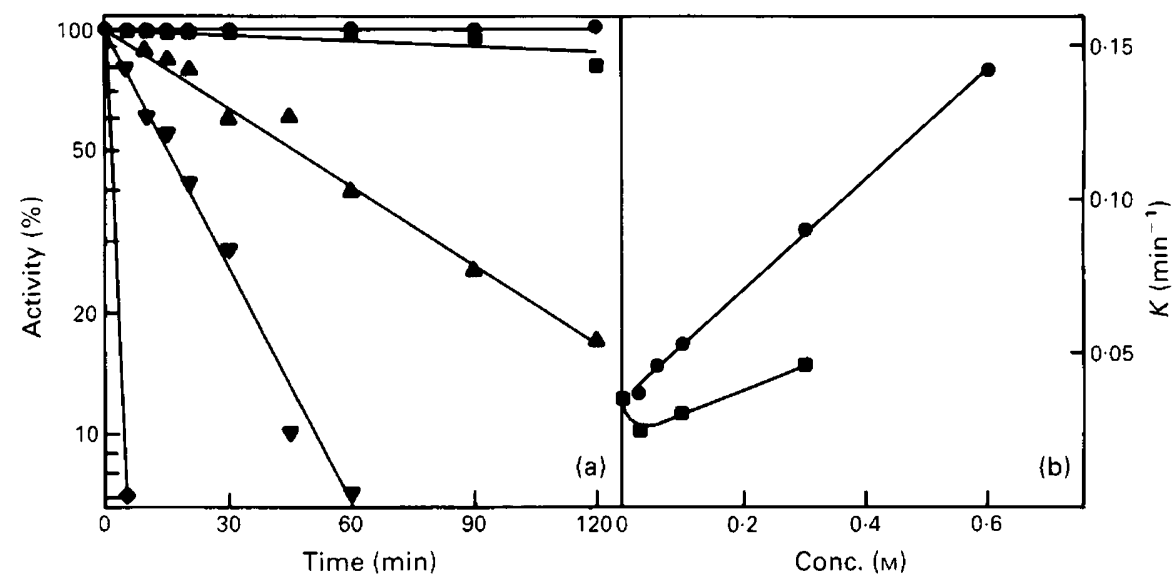

Fig. 4. Heat denaturation of alkaline phosphatase. (a) Alkaline phosphatase in $20 \mathrm{~mm}$-potassium phosphate buffer, $\mathrm{pH} 7.5$, was heated at $40^{\circ} \mathrm{C}(\bullet), 45^{\circ} \mathrm{C}(\boldsymbol{\square}), 50^{\circ} \mathrm{C}(\Delta), 55^{\circ} \mathrm{C}(\boldsymbol{\nabla})$, or $60^{\circ} \mathrm{C}(\bullet)$. At the times shown, $0.1 \mathrm{ml}$ aliquants were removed and assayed for alkaline phosphatase activity. (b) Pseudo first-order rate constants $\left(k^{\prime}\right)$ were calculated from the slopes of heat denaturation curves similar to those shown in Fig. 4(a) but conducted at $55^{\circ} \mathrm{C}$ in buffer containing $\mathrm{NaCl}(\boldsymbol{O})$ or potassium phosphate $(\boldsymbol{\square})$ at the concentrations shown.

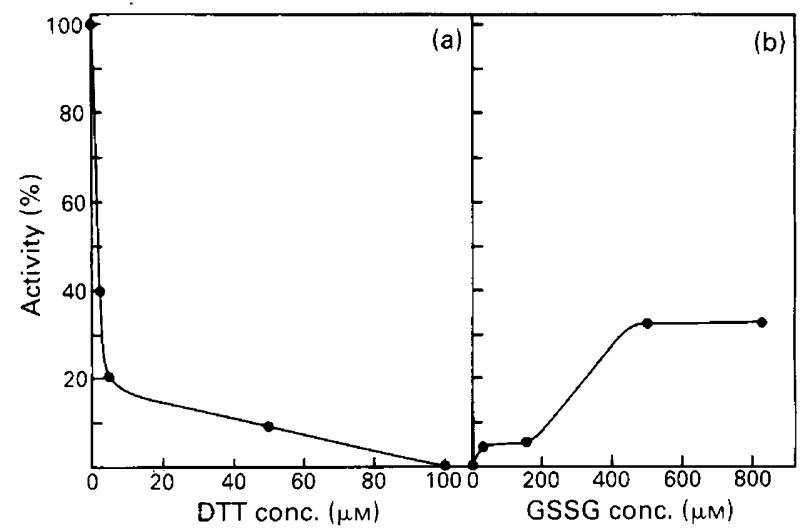

Fig. 5. Effect of dithiothreitol and oxidized glutathione on alkaline phosphatase activity. (a) Reaction mixtures containing 0.17 units of purified alkaline phosphatase $/ \mathrm{ml}$ in $18 \mathrm{~mm}$-potassium phosphate buffer, $\mathrm{pH} 7 \cdot 5$, and dithiothreitol at the concentrations shown were incubated at $30^{\circ} \mathrm{C}$. After $30 \mathrm{~min}, 0.1 \mathrm{ml}$ aliquants were withdrawn and assayed for alkaline phosphatase activity. (b) Aliquants of alkaline phosphatase that had been inactivated by incubation for $30 \mathrm{~min}$ in the presence of $0.1 \mathrm{~mm}$-dithiothreitol were added to equal volumes of oxidized glutathione to give the final concentrations shown. After incubation for an additional $30 \mathrm{~min}$, aliquants were withdrawn and assayed for alkaline phosphatase activity.

seminal plasma, i.e. $0 \cdot 15$ and $0.35 \mathrm{~mm}$ (Strzezek \& Glogowski, 1979), and slightly less than those for the 3 forms from ram seminal plasma, i.e., 0.6, 1.0 and 1.35 mm (Glogowski \& Strzezek, 1981). The $\mathrm{pH}$ optimum for the enzyme from boar seminal plasma was 10 , as opposed to an optimum near 11 with glycine buffer reported for the enzyme forms from ram (Glogowski \& Strzezek, 1981) and bull seminal plasma, though a value near 10 was reported when glycerol 2-phosphate was substrate (Strzezek \& Glogowski, 1979). 


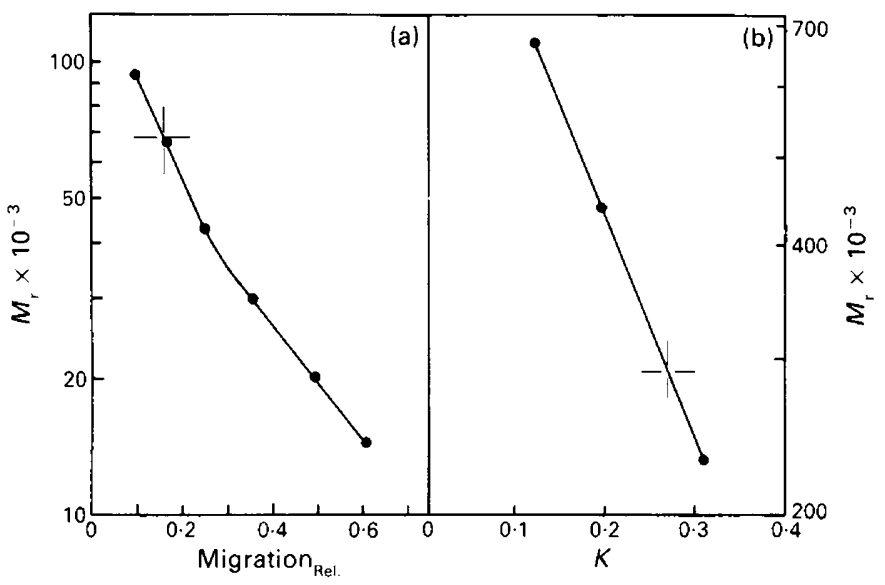

Fig. 6. Molecular weight estimations. (a) Electrophoresis was conducted on a 10-20\% linear gradient of polyacrylamide gel as described by Laemmli (1970). Migration Rel. $_{\text {is }}$ is the ratio of the distances from the top of the gel to the protein band and the tracking dye. The cross shows the relative migration distance of alkaline phosphatase. Protein standards were phosphorylase $b$ $(94000)$, bovine serum albumin $(67000)$, ovalbumin $(43000)$, carbonic anhydrase $(30000)$, soybean trypsin inhibitor (20 100) and $\alpha$-lactalbumin (14400). (b) Sephacryl S-300 chromatography was conducted on a $2 \times 100 \mathrm{~cm}$ column. The column was eluted with $50 \mathrm{~mm}$-potassium phosphate buffer, $\mathrm{pH} 7$, containing $0.1 \mathrm{M}-\mathrm{KCl}$. Protein standards used for calibration were thyroglobulin (669000), ferritin (440000) and catalase $(232000) . \mathrm{K}=\left(\mathrm{V}-\mathrm{V}_{0}\right) /\left(\mathrm{V}_{\text {total }}-\mathrm{V}_{0}\right)$, where $V_{\text {total }}$ is the total volume of the column, $V_{0}$ is the void volume, and $V$ is the elution volume of the protein. The cross shows the value of $\mathrm{K}$ calculated from the elution volume of alkaline phosphatase.

The enzyme from boar seminal plasma appeared to contain zinc like all other alkaline phosphatases (Coleman \& Gettins, 1983). The requirement for both zinc and magnesium to reactivate the apoenzyme was reported for the enzyme from chicken epiphyseal cartilage (Cyboron \& Wuthier, 1981) and for the hepatic alkaline phosphatase isoenzymes, for which high concentrations of zinc also interfered with reactivation (Simon \& Sutherland, 1977). The inhibition of the boar seminal plasma enzyme by the thiols 2-mercaptoethanol and dithiothreitol suggests that disulphide bridges are required for enzyme activity. Alkaline phosphatase from the venom of the brown recluse spider and from bovine fat globule membrane was also inactivated by 2 -mercaptoethanol (Heitz \& Norment, 1974; Basch et al., 1986).

The molecular weight of alkaline phosphatase from boar seminal plasma was approximately 290000 , which, although identical to that of the enzyme from rat ascites hepatoma cells (Yokota, 1978b) and similar to those from cultured rat liver cells (Yokota, 1978a) and chicken epiphyseal cartilage (Cyboron \& Wuthier, 1981), is greater than the molecular weight of most alkaline phosphatases. Molecular weights for the enzyme from human liver (Trepanier et al., 1976), rat intestine (Nakasaki et al., 1979), rat liver (Ohkubo et al., 1974) and human placenta (Harkness, 1968) are about half that of the boar seminal plasma enzyme, and molecular weights of other seminal alkaline phosphatases are 210000 for the three forms from ram seminal plasma (Glogowski \& Strzezek, 1981) and 95000 and 175000 for the two forms from bull seminal plasma (Strzezek \& Glogowski, 1979). The subunit composition of the enzymes from ram and bull seminal plasma was not reported, but alkaline phosphatases from chicken epiphyseal cartilage (Cyboron \& Wuthier, 1981), cultured rat liver cells (Yokota, 1978a) and cultured rat ascites hepatoma cells (Yokota, 1978b), like that from boar seminal plasma, are tetrameric.

This paper is AAES Journal no. 4-861167. 


\section{References}

Arinc, E. (1974) Substructure of horse serum cholinesterase. Ph.D. dissertation, North Carolina State University, Raleigh.

Basch, J.J., Farrell, H.M., Jr \& Malin, E.L. (1986) Isolation of alkaline phosphatase from bovine fat globule membrane. Fedn Proc. Fedn Am. Socs exp. Biol. 45, 1830, Abstr.

Bell, D.J. \& Lake, P.E. (1962) A comparison of phosphomonoesterase activities in the seminal plasmas of the domestic cock, turkey tom, boar, bull, buck rabbit, and of man. J. Reprod. Fert. 3, 363-368.

Bern, H.A. (1949) The distribution of alkaline phosphatase in the genital tract of male mammals. Anat. Rec. 104, 361-370.

Bessey, O.A., Lowry, O.H. \& Brock, M.J. (1946) A method for the rapid determination of alkaline phosphatase with five cubic millimeters of serum. J. biol. Chem. 164, 321-329.

Coleman, J.E. \& Gettins, P. (1983) Alkaline phosphatase. Adv. Enzymol. Rel. Areas Mol. Biol. 55, 381-449.

Cyboron, G.W. \& Wuthier, R.E. (1981) Purification and initial characterization of intrinsic membrane-bound alkaline phosphatase from chicken epiphyseal cartilage. J. biol. Chem. 256, 7262-7268.

Daron, H.H. \& Aull, J.L. (1985) Purification and properties of $\beta-\mathrm{N}$-acetyl-D-hexosaminidase from boar seminal plasma. Int. J. Biochem. 17, 581-588.

Davis, B.J. (1964) Disc electrophoresis. II. Method and application to human serum proteins. Ann. N. $Y$. Acad. Sci. 121, 404-427.

Fernley, H.N. (1971) Mammalian alkaline phosphatases. In The Enzymes, 3rd edn, Vol. 4, Chapt. 18, pp. 417-447. Ed. P. D. Boyer. Academic Press, New York.

Glogowski, J. \& Strzezek, J. (1981) Molecular forms of alkaline phosphatase of ram seminal plasma-some properties and changes in pathological process of reproductive organs. Anim. Reprod. Sci. 3, 307-323.

Harkness, D.R. (1968) Studies on human placental alkaline phosphatase 1. Purification and crystallization. Archs Biochem. Biophys. 126, 503-512.

Hascall, V.C. \& Sajdera, S.W. (1969) Protein polysaccharide complex from bovine nasal cartilage. The function of glycoprotein in the formation of aggregates. J. biol. Chem. 244, 2384-2396.

Heitz, J.R. \& Norment, B.R. (1974) Characteristics of an alkaline phosphatase activity in brown recluse venom. Toxicon 12, 181-187.

Iyer, S., Daron, H. \& Aull, J. (1986) Purification and properties of alkaline phosphatase from boar seminal plasma. Fedn Proc. Fedn Am. Socs exp. Biol. 45, 1805, Abstr.

Keilin, D. \& Hartree, E. F. (1938) On the mechanism of the decomposition of hydrogen peroxide by catalase. Proc. R. Soc., Lond. 124B, 397-405.
Laemmli, U.K. (1970) Cleavage of structural proteins during the assembly of the head of bacteriophage T4. Nature, Lond. 227, 680-685.

Lowry, O.H., Rosebrough, N.J., Farr, A.L. \& Randall, R.J. (1951) Protein measurement with the Folin phenol reagent. J. biol. Chem. 193, 265-275.

Mann, T. (1964) The Biochemistry of Semen and of the Male Reproductive Tract, pp. 191-192. Methuen, London.

McComb, R.B., Bowers, G.N. \& Posen, S. (1979) Alkaline Phosphatase. Plenum Press, New York.

Muller, B. (1983) Genital tract proteins in the male rabbit. II. Alkaline phosphatase-enzyme action and site of synthesis. Andrologia 15, 676-681.

Nakasaki, H., Matsushima, T., Sato, S. \& Kawachi, T. (1979) Purification and properties of alkaline phosphatase from the mucosa of rat small intestine. $J$. Biochem. 86, 1225-1231.

O'Farrell, P.H. (1975) High resolution two-dimensional electrophoresis of proteins. J. biol. Chem. 250, 4007-4021.

Ohkubo, A., Langerman, N. \& Kaplan, M.M. (1974) Rat liver alkaline phosphatase. Purification and properties. J. biol. Chem. 249, 7174-7180.

Simon, F.R. \& Sutherland, E. (1977) Hepatic alkaline phosphatase isozymes: isolation, characterization and differential alteration. Enzyme 22, 80-90.

Stallcup, O.T. (1965) Acid and alkaline phosphatase activity in bovine semen as related to fertility. J. Dairy Sci. 48, 752-754.

Starkweather, W.H. \& Searcy, R.L. (1975) Evaluation of a new indigogenic substrate for demonstrating serum alkaline phosphatase isoenzymes. Clin. Chem. 21, 968.

Strzezek, J. \& Glogowski, J. (1979) Molecular forms of alkaline phosphatase in bull seminal plasma. I. Isolation and characterization of two forms. Int. J. Biochem. 10, 135-146.

Trepanier, J.M., Seargeant, L.E. \& Stinson, R.A. (1976) Affinity purification and some molecular properties of human liver alkaline phosphatase. Biochem. $J$. $155,653-660$.

Van Belle, H., DeBroe, M.E. \& Wieme, R.J. (1977) L-pBromotetramisole, a new reagent for use in measuring placental or intestinal isoenzymes of alkaline phosphatase in human serum. Clin. Chem. 23, 454-459.

Vittur, F. \& Debernard, B. (1973) Alkaline phosphatase activity associated to a calcium binding glycoprotein from calf scapula cartilage. FEBS Lett. 38, 87-90.

Yokota, Y. (1978a) Purification and characterization of alkaline phosphatase in cultured rat liver cells. J. Biochem. 83, 1285-1292.

Yokota, Y. (1978b) Purification and characterization of alkaline phosphatase from cultured rat ascites hepatoma cells. J. Biochem. 83, 1293-1298.

Received 13 July 1987 